\title{
Effect of Different Sowing Dates and Varieties on Growth and Yield of Lentil (Lens Culinaris Medikus) in the Highland Vertisols of North Shewa, Ethiopia
}

\author{
Mebrate Tamrat Woldeselassie, Daniel Admasu* \\ Debre Birhan Agricultural Research Center, P.O.Box 112, Debre Birhan, ETHIOPIA \\ *Email for Correspondence: admasudaniel@gmail.com
}

\begin{abstract}
Field experiments were carried out to study the response of two lentil varieties to varying sowing dates in a split plot design with three replications, in which varieties were assigned to main plots and sowing dates to sub plots. The study was conducted at Enewari research site of Debre Birhan agricultural research center for three consecutive years (2007 - 2009) on two soil types. The results showed that no significant difference between varieties for grain yield. However, variety Alemaya produced highest grain yields of $1.3 \mathrm{t} / \mathrm{ha}$ and $1.22 \mathrm{t} / \mathrm{ha}$ from fifth (30-July) sowing date on heavy and relatively light Vertisols respectively. On the other hand, the local variety produced highest grain yields of $1.4 \mathrm{t} / \mathrm{ha}$ and $1.06 \mathrm{t} / \mathrm{ha}$ on the fifth and six sowing dates on heavy and relatively light Vertisols respectively. Grain yield proportionally increased with increasing biological yield in different sowing dates on both soil types. On heavy Vertisol varieties responded differently to the changes of sowing dates. Variety Alemaya had responded to a wider sowing dates. Early August to mid-August sowing found to be optimum for local variety. On light Vertisol, the functional relationship was unexplained for both varieties. In general, heavy Vertisol gave higher responses than relatively light vertisol throughout most parameters and levels tested.
\end{abstract}

Key words: Variety, heavy and relatively light Vertisols

\section{INTRODUCTION}

Lentil (Lens culinaris M.) is an important cool season food legume in Ethiopia. It is almost a cash crop because it fetches very high prices compared with all other food legumes and main cereal crops such as tef, wheat and barley (DZARC, 1997). The demand for this commodity both in local and international markets has increased significantly in recent years. It is often claimed that the internal (local) market seriously competes with the external market (Frehiwot, 2009).

It is one of the highland pulse crops grown in North Shewa, covering 25,870.79 hectares of land next to faba bean (41,747 hectares of land). Its productivity is estimated to be 1.3 tons per hectare as compared to 1.26 tons per hectare national average (CSA, 2014) and 1 ton per hectare in the world (Frehiwot, 2009). Ethiopia is among the top ten lentil producing countries in the world (Factfish, 2013) and ranks first in its production and acreage in Africa followed by Eritrea, Morocco, Egypt and Tunisia (Tadele et al., 2014). Ethiopia was $8^{\text {th }}$ from top ten lentil-producing countries and has a world share of $\mathbf{2 . 6 \%}$ during the year 2012. The production quantity has increased from 36,000 tons in 1961 to 129,833 tons in 2013, though the increment lacks consistency from year to year (Factfish, 2013).

However, its average grain yield has remained very low (Frehiwot, 2009). This is due to several biotic and abiotic production practices limitations that hinder the productivity of the crop. Time of sowing is one of the factors known to affect plant growth, development and assimilate partitioning that, in turn, affect final yield (Khalil et al., 2010). Moreover, according to Saxena (1981), the date of sowing markedly affects the performance of lentils because of the 
change in the environmental conditions to which the crop is exposed at various stages of phenological development under different dates. Hence, it is an important agronomic variable in optimizing the seed yields of lentil. Optimum date varies with location and is dependent upon both metrological condition and the specific lentil cultivar (Million, 1994). It is also stated that lentil sowing time varies from place to place depending on the amount and distribution of rainfall, temperature, topography and elevation of the area. Sloppy and light soil fields are planted very early as compared to gentle sloppy and flat plain Vertisols and flooded areas. Usually, early planting produces more yield than late planting (Roy, 2009, Moosavi et al., 2014), though early planting exposes lentil to insect pests, diseases and waterlogging which affect its productivity (Senait et al., 2006). Similarly, Sehirali (1988) reported that late planting will decrease yield and increase protein content.

In general, late June to mid-July planting is recommended in both mid to high altitude areas of Ethiopia. A small proportion of lentil is produced during the short rainy season (April - May) in some parts of Bale, east and west Harerghe zones (Senait et al., 2006). However, Experiments conducted in the central highlands at Enewari and Tefki (Debrezeit) during1982-1984 showed that the early July to mid-August planting was found to be optimum for planting the local and exotic lentils (Million, 1994; Adamu and Zewudu, 1998). Farmers in North Shewa usually plant lentil in early July on relatively light Vertisol and in August on heavy Vertisol (Mererie) where broad bed and furrow (BBF) production system is practiced and in early September on flat land using residual moisture (field reports ). According to observations made, farmers' sowing dates are not optimum for the productivity of lentil. Therefore, this experiment was initiated to find out the optimum sowing date in the broadcast method of sowing for early and late maturing lentil cultivars on relatively light and heavy Vertisols.

Objective: To determine optimum sowing date of lentil cultivars for higher productivity on Vertisols of North Shewa highlands.

\section{Materials AND Methods}

\section{Description of Experimental Site and Materials}

The experiment was conducted at Enewari on two soil types that represent relatively light and heavy Vertisols as classified by farmers practice for three consecutive years (2007-2009). The study area is located at an altitude of 2665 meters above sea level (masl), latitude of $9^{0} 53^{\prime} \mathrm{N}$ and a longitude of $39^{0} 10^{\prime} \mathrm{E}$ with an average annual rainfall of $898 \mathrm{~mm}$ (Info Arari, 2004). One improved cultivar (Alemaya) which is relatively late (114 - 143 days to maturity) and large seed size as well as one local cultivar which is relatively early (99-126 days to maturity) and smaller seed size as compared to Alemaya were used.

\section{Experimental Design and treatments}

Spilt-plot design in RCB with three replications was employed. Main plot treatments were two lentil cultivars (alemaya and local). Sub-plot treatments were six sowing dates in ten days interval starting from $10^{\text {th }}$ of July and ending in $29^{\text {th }}$ of August. Main plot size of $127.2 \mathrm{~m}^{2}$ and sub-plot size of $19.2 \mathrm{~m}^{2}$ was implemented. A sub-plot comprised four broad beds each with $0.8 \mathrm{~m}$ width and $0.4 \mathrm{~m}$ furrows between beds. All necessary data was collected from net plot area of $9.6 \mathrm{~m}^{2}$. Alley space of $0.6 \mathrm{~m}$ between plots, and $1 \mathrm{~m}$ between main plots and between replications was used.

\section{Experimental Procedures}

Sowing was done by using handmade broad bed and furrow (BBF). During 2007 the beds were prepared while sowing in each sowing date and the experimental plots were muddy while preparing the beds, during 2008 the beds were prepared earlier than the first sowing for all sowing dates and during 2009 the beds were prepared similar to 2008, but there was unusual rainfall until harvesting. While analyzing the data all these situations are considered as good opportunities to explore probable causes of unusual events as stated in Gomez and Gomez (1984). A broadcast seeding rates of $110 \mathrm{Kg} / \mathrm{ha}$ and $80 \mathrm{Kg} / \mathrm{ha}$ for Alemaya and Local cultivars were administered respectively. DAP fertilizer was applied at a rate of $100 \mathrm{~kg} / \mathrm{ha}$ during planting. Other management practices were implemented as per the recommendation.

\section{Data Collection and Analysis}

Grain yield, biological yield and other agronomic parameters, viz., stand count at emergence, date of flowering, plant height, disease score, number of pods per plant, number of seeds per pod, date of maturity and 100- seeds weight was recorded. However, data collection was inconsistent from year to year. Hence, analysis of variance and trend analysis using polynomial contrasts in general linear regression was carried out for grain yield, biological yield as well as for harvest index by the use of GenStat Release 16.1 (PC/Windows 7), Copyright 2013, and VSN International Ltd. Before performing combined analysis of different years and locations, a quick test of homogeneity of variance was performed as indicated in Peterson (1994). Accordingly, the variances found homogeneous. However, the combined analysis of 
both soil types revealed that the presence of highly significant variation among soil types for all the parameters tested. Accordingly, separate combined analysis was done for each soil type across years.

\section{Results AND Discussion}

Results of combined analysis of variance over years revealed that biological yield and grain yield were significantly $(\mathrm{P} \leq 0.01)$ affected by year differences on both soil types whereas harvest index was not. This was probably related to bed preparation time during 2007 crop season which may influence emergence of seeds and extended rainfall during 2009 crop season which influenced maturity and harvesting time of the cultivars. Biological yield and harvest index were significantly $(\mathrm{p} \leq 0.05)$ responded to the main effect of cultivars of lentil on both soil types whereas grain yield was not (Table 1). However, cultivar alemaya produced higher grain yield than the local cultivar on both soil types. On the other hand, the local cultivar had significantly higher harvest index than cultivar alemaya on both soil types (Table 2). This could be attributed to higher partitioning rate of biomass to grain yield by local cultivar than alemaya as it is early maturing than alemaya. Late sowing may affect assimilate partitioning rate of late maturing cultivars (Khalil et al., 2010). Main effect of sowing date and interaction of year and sowing date significantly $(\mathrm{P} \leq 0.05)$ influenced the response of all parameters on both soil types (except harvest index on heavy Vertisol). This result agrees with the results reported by Roy (2009) and Moosavi et al. (2014). On the other hand, only grain yield and harvest index were significantly $(\mathrm{P} \leq 0.05)$ affected by the interaction of cultivar and sowing date on heavy Vertisol. Three-way interaction of year by cultivar by sowing date was not significant for both soil types (except biological yield on heavy Vertisol). This indicates that the varieties performed in a similar manner across three years for most parameters tested (Table 1).

Table 1: Summary of combined analysis of variance of grain yield, biological yield and harvest index on heavy and relatively light vertisol.

\begin{tabular}{|lccccccc|}
\hline & \multicolumn{3}{c}{ Heavy Vertisol } & \multicolumn{4}{c|}{ Light Vertisol } \\
\cline { 2 - 8 } Source of variation & d.f. & BM & GY & HI & BM & GY & HI \\
\cline { 2 - 8 } Year & 2 & $* *$ & $* *$ & ns & $* *$ & $* *$ & ns \\
Cultivar & 1 & $* *$ & ns & $* *$ & $* *$ & ns & $*$ \\
Year X Cultivar & 2 & ns & $*$ & ns & ns & ns & $*$ \\
Sdate & 5 & $* * *$ & $* * *$ & ns & $* *$ & $*$ & $*$ \\
Year X Sdate & 10 & $* *$ & $* *$ & ns & $* * *$ & $* * *$ & $* * *$ \\
Cultivar X Sdate & 5 & ns & $*$ & $*$ & ns & ns & ns \\
Year X Cultivar X Sdate & 10 & $*$ & ns & ns & ns & ns & ns \\
\hline
\end{tabular}

* Significant at 5\%; ** Significant at $1 \% ; * *$ Significant at $0.1 \%$

The maximum biological yields of $3 \mathrm{t} /$ ha and $2.4 \mathrm{t} /$ ha as well as grain yields of $1.4 \mathrm{t} /$ ha and $1.09 \mathrm{t} / \mathrm{ha}$ were obtained on heavy and relatively light Vertisols respectively from fifth sowing date (19-August). The highest and significant harvest index was obtained from the last sowing date (29-August) on relatively light Verisol. After fifth sowing date both biological and grain yield started to decrease on both soil types. In general, heavy Vertisol gave higher biological and grain yields and harvest index than relatively light Vertisol throughout the tested levels (except first sowing date for grain yield and last sowing date for harvest index on both soil types) (Table 2).

Table 2: Biological yield ( $t /$ ha), grain yield ( $\mathrm{t} / \mathrm{ha}$ ) and harvest index of lentil as affected by variety and sowing dates on heavy and relatively light Vertisols during 2007-2009.

\begin{tabular}{|c|c|c|c|c|c|c|}
\hline & \multicolumn{3}{|c|}{ Heavy Vertisol } & \multicolumn{3}{|c|}{ Relatively light Vertisol } \\
\hline & $\mathrm{BM}$ & GY & $\mathrm{HI}$ & $\mathrm{BM}$ & GY & $\mathrm{HI}$ \\
\hline \multicolumn{7}{|l|}{ Variety } \\
\hline Alemaya & $2.8 \mathrm{a}$ & 1.2 & $0.43 b$ & $2.4 \mathrm{a}$ & 1.0 & $0.42 b$ \\
\hline Local & $2.3 b$ & 1.1 & $0.49 a$ & $2.0 \mathrm{~b}$ & 0.9 & $0.46 a$ \\
\hline $\mathrm{LSD}(\mathrm{P} \leq 5 \%)$ & 0.1528 & ns & 0.0255 & 0.1568 & ns & 0.0273 \\
\hline \multicolumn{7}{|l|}{ Sowing date } \\
\hline 10-July & $1.80 \mathrm{~d}$ & $0.82 \mathrm{c}$ & 0.45 & $2.05 b$ & $0.89 \mathrm{~b}$ & $0.41 b$ \\
\hline 20-July & $2.49 c$ & $1.12 \mathrm{~b}$ & 0.46 & $2.25 \mathrm{ab}$ & $0.94 \mathrm{ab}$ & $0.41 b$ \\
\hline 30-July & $2.69 b c$ & $1.21 \mathrm{~b}$ & 0.45 & $2.18 \mathrm{ab}$ & $0.92 b$ & $0.43 b$ \\
\hline 9-August & $2.71 b c$ & $1.21 \mathrm{~b}$ & 0.46 & $2.26 a b$ & $0.95 \mathrm{ab}$ & $0.43 b$ \\
\hline 19-August & $3.00 \mathrm{a}$ & $1.34 \mathrm{a}$ & 0.46 & $2.42 a$ & $1.09 a$ & $0.46 \mathrm{ab}$ \\
\hline 29-August & $2.78 \mathrm{ab}$ & $1.28 \mathrm{ab}$ & 0.47 & $2.21 \mathrm{ab}$ & $1.07 \mathrm{a}$ & $0.49 a$ \\
\hline LSD $(\mathrm{P} \leq 5 \%)$ & 0.2647 & 0.1451 & ns & 0.2716 & 0.1429 & 0.0473 \\
\hline
\end{tabular}

$\mathrm{BM}=$ above ground biological yield, GY=Grain yield, $\mathrm{HI}=$ Harvest index 
Interaction effect of cultivar and sowing date significantly influenced only grain yield and harvest index on heavy Vertisol. However, the result is presented in Table 3 for all parameters on both soil types as the main effect of cultivars affected the response of biological yield and harvest index. The results showed that cultivar alemaya produced highest grain yields of $1.3 \mathrm{t} / \mathrm{ha}$ and $1.22 \mathrm{t} / \mathrm{ha}$ from fifth (30-July) sowing date on heavy and relatively light Vertisols respectively. On the other hand, the local cultivar produced highest grain yields of $1.4 \mathrm{t} / \mathrm{ha}$ and $1.06 \mathrm{t} / \mathrm{ha}$ on the fifth and six sowing dates on heavy and relatively light Vertisols respectively. Trend comparison was found significant only for local cultivar on heavy Vertisol (Figure 1). However, the response curve showed that sowing time was much extended for cultivar alemaya starting from second sowing date (20 July) up to fifth sowing date (19-August) than the local cultivar, which begins from the fourth sowing date (9-August). This result goes in line with the actual farmer's practice where cultivar alemaya is being sown earlier than the local cultivar. Moosavi et al., (2014) commented that longer growth period allows the plants to have enough opportunity for branch-bearing and producing more reproductive organs. In addition to this, cultivar alemaya is long maturing and could be more exposed to frost than the local cultivar if sown late. Irrespective of the cultivars, trend comparison showed that mid-July up to mid-August sowing seemed optimum on heavy Vertisol whereas no clear difference between early and late sowing on relatively light Vertisol, though August sowing seemed better (Figure 2).

Table 3: Grain yield, biological yield and harvest index as affected by sowing dates and lentil cultivars on heavy Vertisol and relatively heavy Vertisol during 2007-2009 crop seasons.

\begin{tabular}{|l|l|c|c|c|c|c|c|}
\hline & & \multicolumn{3}{|c|}{ Heavy vertisol } & \multicolumn{3}{c|}{ Relatively light vertisol } \\
\cline { 3 - 8 } Cultivar & Sowing date & BM & GY & HI & BM & GY & HI \\
\hline Alemaya & 10-July & 2.06 & 0.96 & 0.48 & 2.27 & 0.89 & 0.37 \\
\hline Alemaya & 20-July & 2.80 & 1.21 & 0.43 & 2.31 & 0.91 & 0.39 \\
\hline Alemaya & 30-July & 3.09 & 1.26 & 0.40 & 2.41 & 1.00 & 0.43 \\
\hline Alemaya & 9-August & 3.01 & 1.24 & 0.42 & 2.46 & 0.94 & 0.38 \\
\hline Alemaya & 19-August & 3.16 & 1.30 & 0.42 & 2.81 & 1.22 & 0.44 \\
\hline Alemaya & 29-August & 2.94 & 1.22 & 0.42 & 2.25 & 1.09 & 0.49 \\
\hline Local & 10-July & 1.54 & 0.67 & 0.43 & 1.84 & 0.88 & 0.45 \\
\hline Local & 20-July & 2.18 & 1.03 & 0.48 & 2.19 & 0.97 & 0.44 \\
\hline Local & 30-July & 2.30 & 1.16 & 0.49 & 1.96 & 0.84 & 0.44 \\
\hline Local & 9-August & 2.41 & 1.17 & 0.49 & 2.06 & 0.96 & 0.48 \\
\hline Local & 19-August & 2.84 & 1.40 & 0.51 & 2.03 & 0.96 & 0.48 \\
\hline Local & 29-August & 2.62 & 1.30 & 0.51 & 2.16 & 1.06 & 0.49 \\
\hline Interaction & & ns & $*$ & $*$ & ns & ns & ns \\
\hline
\end{tabular}

$\mathrm{BM}=$ above ground biological yield, $\mathrm{GY}=$ Grain yield, $\mathrm{HI}=$ Harvest index

Figure 1: Mean grain yields of two lentil cultivars (alemaya and local) as affected by sowing dates on heavy vertisol at Enewari, 2007-2009

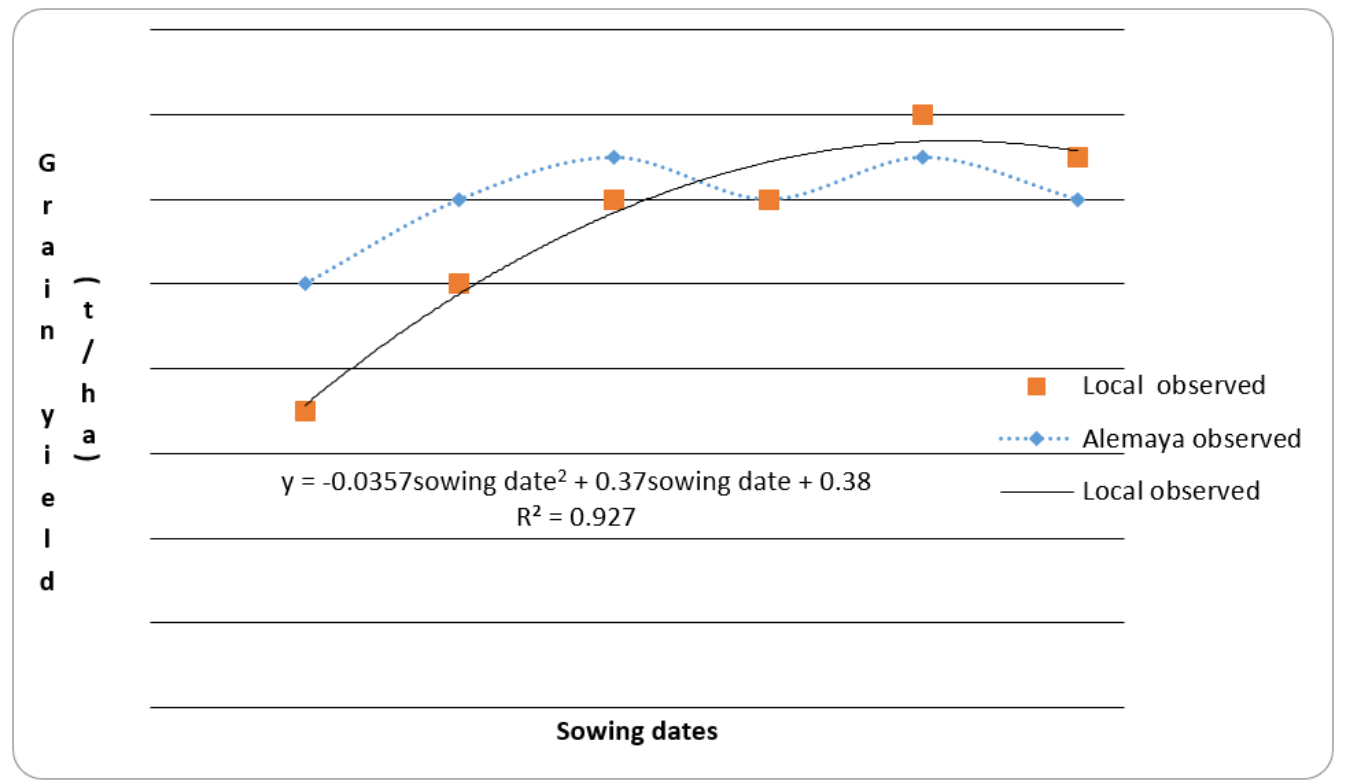

Sowing dates: 1=10-July, 2=20-July, 3=30-July, 4=9-August, 5=19-August, 6=29-August 
Figure 2: Mean grain yield response of heavy and relatively light Vertisol for two lentil cultivars (alemaya and local) as affected by sowing dates at Enewari, 2007-2009

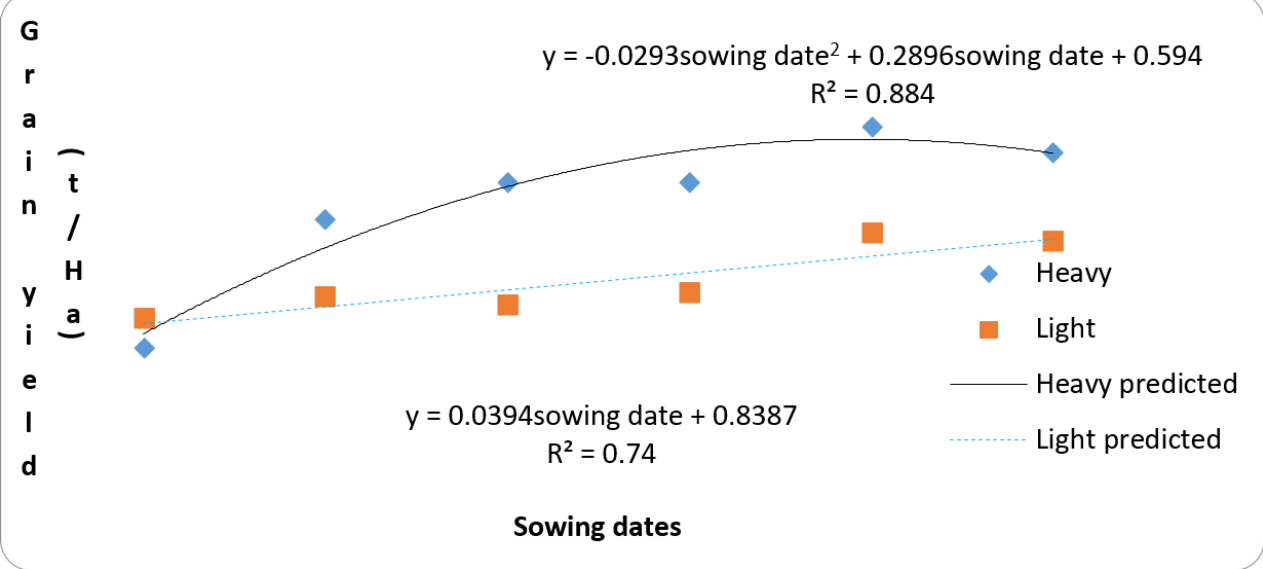

Sowing dates: 1=10-July, 2=20-July, 3=30-July, 4=9-August, 5=19-August, 6=29-August

\section{CONCLUSION}

In this study, on heavy Vertisol varieties responded differently to the changes of sowing dates. Accordingly, the late maturing variety Alemaya had responded to a wider sowing dates starting from July 19 until the end of August, but to escape the excess rainfall at early stages and the late coming frost early planting (July 30 to August 09) found to be optimum. On the other hand, early August to mid-August found to be optimum for local variety. On relatively light Vertisol, the functional relationship was unexplained for both varieties and also the interaction was none significant.

\section{ACKNOWLEDGMENTS}

The authors are most grateful for Debre Birhan Agricultural Research Center, for research funding supports of this study.

\section{REFERENCES}

Adamu Molla and Zewdu Yilma.1998. Agronomy Research in North Shewa, Pp118-125. In: Beyene Seboka and Aberra Deressa (eds.) 1998. Agriculture Research and Technology Transfer Attempts and Achievements in Northern Ethiopia, 18-21. Proceedings of the Fourth Technology Generation, Transfer and Gap Analysis Workshop. March 1997, Bahir Dar, Ethiopia

CSA (Central Statistical Agency). 2014. Agricultural sample survey, report on area and production of major crops, volume I, Private Holdings, Meher Season, Statistical bulletin 532, Addis Ababa.

DZARC (Debre zeit Agricultural Research Center).1997. Released Lentil Varieties production Package (Amharic version) Leaflets. DZARC.EARO: Debre Zeit, Ethiopia.

Factfish. 2013. Ethiopia: Lentils, production quantity (tons). http:/ /www.factfish.com/imprint (accessed on June 30, 2015).

Frehiwot Mulugeta. 2009. Ethiopia Commodity Exchange Authority Lentil Production, Supply, Demand and Marketing issues in Ethiopia.

Gomez, A and A. Gomez. 1984. Statistical Procedure for Agricultural Research. $2^{\text {nd }}$ edition. John Wiley and sons. Inc.

Info Arari. 2004. Amhara Agricultural Research Institute (ARARI) Biometrics and Information Technology Management Unit. Bahir Dar.

Khalil, S. K., Wahab, A., Rehman, A., Fida, M., Wahab, S., Khan, A. Z., Zubair, M., Shah, M.K., Khalil, I. H., and Amin, R., 2010. Density and planting date influence phonological development assimilate partitioning and dry matter production of faba bean. Pakistan Journal of Botany, 42(6): 3831-3838.

Million Eshete.1994. Chickpea and Lentil Agronomy Research. pp230-250. Asfaw Telaye, Geletu Bejiga, Mohan C. Saxena, and Mohamoud B. Solh, (Eds.). Cool- Season Food Legumes of Ethiopia. Proceedings of the First National Cool-Season Food Legumes Review Conference, 16-20 December 1993, Addis Ababa, Ethiopia. ICARDA: Aleppo, Syria. Vii+40 pp.

Moosavi, S.G., Seghatoleslami, M.J., and Delarami, M.R. 2014. Effect of Sowing Date and Plant Density on Yield and Yield Components of Lentil (Lens culinaris cv. Sistan). Annual Research \& Review in Biology 4(1): 296-305.

Roy, A., Aich, S. S., Bhowmick, M. K., and Biswas, P. K. 2009. Response of lentil varieties to sowing time in the plains of West Bengal. Journal of Crop and Weed, 5(2): 92-94.

Saxena, M.C. 1981. Agronomy of Lentil. In: Commonwealth Agricultural Bureaux. pp. 111-129.

Sehirali,S. 1988. Grain Legume Crops, 1089 (314), p. 435. Ankara University, Faculty of Agricultural Engineering, Ankara, Turkey.

Senait Regassa, Legesse Dadi, Demissie Mitiku, Asnake Fikre, 2006. Impact of technologies in selected lentil growing areas of Ethiopia: EIAR research report number 67. 
Woldeselassie and Admasu: Effect of Different Sowing Dates and Varieties an Growth and Yield af Lentil (Lens Culinaris Medikus) in the Highland Vertisals uf Narth Shewa, Ethiapia (II7-I22)

SHARC (Sheno Agricultural Research Center). 2001. Cool-Season Food Legumes Research Annual Report for the year 200/20001, Sheno Agricultural Research Center (ShARC), Sheno, Ethiopia.

Tadele Tadesse, Teshome Leggesse, Behailu Mulugeta and Gashaw Sefera. 2014. Correlation and path coefficient analysis of yield and yield components in lentil (Lens culinaris Medik.) germplasm in the highlands of Bale, Ethiopia, International Journal of Biodiversity and Conservation, Vol. 6(1), pp. 115-120.

-- 0 --

MJMBR listed in CSE member's journals database

http://www.councilscienceeditors.org/about/members-journals/

Indexed in Google Scholar

https://scholar.google.com/citations?hl=enanduser=JH23W_8AAAAI

MJMBR Following the ICMJE Recommendations (list date 7/1/14)

http://www.icmje.org/recommendations/

RoMEO: This is a RoMEO blue journal

http://www.sherpa.ac.uk/romeo/search.php?issn=2313-0008

Author's Pre-print: author cannot archive pre-print (ie pre-refereeing)

Author's Post-print: author cannot archive post-print (ie final draft post-refereeing)

Publisher's Version/PDF: author can archive publisher's version/PDF

(C) $(1) \Theta$

This journal is licensed under a Creative Commons Attribution-NonCommercial 4.0 International License.

Articles can be read and shared for noncommercial purposes under the following conditions:

- BY: Attribution must be given to the original source (Attribution)

- NC: Works may not be used for commercial purposes (Noncommercial)

This license lets others remix, tweak, and build upon your work non-commercially, and although their new works must also acknowledge you and be non-commercial, they don't have to license their derivative works on the same terms.

License Deed Link: http://creativecommons.org/licenses/by-nc/4.0/

Legal Code Link: http://creativecommons.org/licenses/by-nc/4.0/legalcode

MJMBR uses the CC BY-NC to protect the author's work from misuse. 